\title{
Evaluation of sorption of lindane on activated carbon derived from rice straw and fungal biomass of Phanerochaete chrysosporium
}

\author{
Ahmed AbdelGawad El-Kady', Tarek Samir Jamil2*, \\ Abd El-Nasser Abd El-Hafez Khattab³, Hany Hussien Abdel Ghafar ${ }^{2}{ }^{4}$

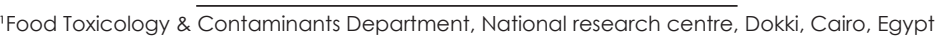 \\ ${ }^{2}$ Water Pollution Research Department, National research centre, Dokki, Cairo, Egypt \\ ${ }^{3}$ Genetics and Cytology Department, National Research Centre, Dokki, Cairo, Egypt \\ ${ }^{4}$ Chemistry Department, Faculty of Science and Arts, Khulais, University of Jeddah, Saudi Arabia \\ *Corresponding author, e-mail: omaytarek73@yahoo.com
}

\begin{abstract}
Rice straw was used for preparation of activated carbon using chemical activation by impregnation with concentrated $\mathrm{H}_{3} \mathrm{PO}_{4}$ followed by pyrolysis at $500{ }^{\circ} \mathrm{C}$ for $2 \mathrm{~h}$. Physicochemical properties were investigated by several procedures; elemental analysis, scan electron microscope and porosity characteristics. Batch experimental mode was applied for adsorption and biosorption studies. A matrix effect analysis is applied to correlate the lindane adsorption or biosorption capacity to the agitation time, initial levels of lindane and carbon dose or biosorbent concentration. The Scanning Electron Microscope images equipped with Energy-dispersive X-ray reflect the enhancement of thermo-chemical activation by $\mathrm{H}_{3} \mathrm{PO}_{4}$ in increasing the porosity of AC. Sorption behavior of Lindane by Activated Carbon (AC) and Phanerochaete chrysosporium, respectively have been studied to compare the obtained results in order to consider cost effective method for agriculture wastewater treatment. The adsorption capacity and distribution coefficients were determined for the adsorption system as a function of sorbate concentration. Under the studied concentrations, the adsorption of lindane by AC and its biosorption by Phanerochaete chrysosporium match to Langmuir as well as Freundlich isotherms. Afterword, adsorption and biosorption behavior was assessed by calculation of constants for each isothermal model. Finally, Biosorption of Lindane by Phanerochaete chrysosporium showed higher and faster removal compared with AC derived from rice straw.
\end{abstract}

Keywords: Activated Carbon, Lindane, Phanerochaete Chrysosporium, Rice Straw, Sorption.

\section{Avaliação da sorção de lindano sobre carvão ativado derivado de palha de arroz} e biomassa fúngica de Phanerochaete chrysosporium

\section{Resumo}

Utilizou-se palha de arroz para a preparação de carvão ativado por ativação química por impregnação com $\mathrm{H}_{3} \mathrm{PO}_{4}$ concentrado seguido de pirólise a $500{ }^{\circ} \mathrm{C}$ por $2 \mathrm{~h}$. As propriedades físicoquímicas foram investigadas por vários procedimentos; Análise elementar, microscopia eletrônica de varredura e características de porosidade. O modo experimental em lote foi aplicado para estudos de adsorção e biossorção. Uma análise de efeito de matriz é aplicada para correlacionar a capacidade de adsorção ou de biossorção de lindano com o tempo de agitação, os níveis iniciais de lindano e dose de carbono ou concentração de biossorvente. As imagens do microscópio eletrônico de varredura, equipadas com raios $X$ de dispersão de energia, refletem o aumento da ativação termoquímica por $\mathrm{H}_{3} \mathrm{PO}_{4}$ no aumento da porosidade de AC. O comportamento de sorção do Lindano por Carvão Ativado (AC) e Phanerochaete chrysosporium, respectivamente, tem sido estudado para comparar os resultados obtidos, a fim de considerar o método de custo efetivo para o tratamento de águas residuais da agricultura. A capacidade de adsorção e os coeficientes de distribuição foram determinados para o sistema de adsorção em função da concentração de sorbato. Sob as concentrações estudadas, a adsorção de lindano por AC e sua biossorção por Phanerochaete chrysosporium combinam-se a Langmuir assim como isotermas de Freundlich. O comportamento de adsorção e biossorção foi avaliado por cálculo de constantes para cada modelo isotérmico. Finalmente, a Biossorção de Lindano por Phanerochaete chrysosporium mostrou maior e mais rápida remoção comparada com AC derivada de palha de arroz.

Palavras-chave: Carvão ativado, Lindano, Phanerochaete chrysosporium, Palha de arroz, Sorção. 


\section{Introduction}

Activated carbon (AC) adsorption has been cited by the US Environmental Protection Agency (US-EPA) as one of the best available environmental pollution control technologies (USEPA, 2012) due to its cost effectiveness (Kadirvelu et al., 2005). US-EPA stated that AC is needed to control mercury or dioxin and furan emissions. AC is widely used as adsorbent either in liquid or in gas phase (Sivakumar et al., 2012). Synthesized resin, wood, coal and agriculture waste are the most common sources for carbon production with high adsorption capacity that can be used for particular purpose after its activation either chemically or physically (Abdul Khalil et al., 2013). The physical properties of the prepared $A C$ is dependant up on typing of starting materials from which carbon is prepared as well as method and conditions of preparation (An et al., 2011). Agriculture wastes are widely used as source for AC preparation. The most common raw materials used for the production of AC are rice husk (Guo et al., 2005), grape seed (Özçimen and ErsoyMeriçboyu, 2009), waste tyres (Lopez et al., 2009), date stones (El-Kady et al., 2013a,b), hazelnut shell (Demirbaş et al., 2002) etc. AC prepared from rice husk is used for removal of several pollutants from water such as dyes (Rahman et al., 2012) and heavy metals (Singh and Singh, 2012).

Unlike metals, many organic compounds released into the environment are degraded by natural microbial populations, and such biodegradation potential is the basis of many established and emerging treatment processes (Fomina and Gadd, 2014).

Biosorption has been promoted as a potential biotechnology for removal of organic substances from waste streams and effluents. One of the highly persistent organochlorine is lindane ( $\mathrm{Y}$-hexachlorocyclohexane), which used in agriculture and medicine to world level.

Acceptable concentration level of pesticides in drinkable water was tightened following the introduction of new standards for drinkable water. The amount of a single pesticide can't exceed $0.1 \mu \mathrm{g} / \mathrm{l}$ while the sum of all pesticide concentrations must not exceed

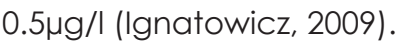

A set of requirements established to select the most promising types of biomass from large pool of readily available and inexpensive biomaterials. In this respect, the biosorbent should be available in low-cost and could come from industrial wastes, which are available at low cost; the organisms easy to obtain in large amount and can be grown easily for biosorption (Park et al., 2010).

Reports are available on biosorption of lindane by some gram positive and gram negative bacteria, e.g., Escherchia coli, Bacillus subtilis and adsorption of lindane onto humic acid parenthesis a natural organic matter of soil (Ju et al., 1997, Prosen et al., 2002). Lindane firstly contacts the extra-mycelia surface before being degraded or adsorbed. The interaction process on the mycelia surface has potential effects on degradation, bioavailability, and absorption of organic pollutants in soil and then conducts detoxification. Especially, biosorption covers a number of metabolism-independent processes, including physical and chemical adsorption, complexation, chelation, and microprecipitation in the cell wall (Aksu, 2005). Furthermore, the genetic development of new strains using mutagenesis for increasing the rate of the biosorption processes are applied by Yavuz et al. (2006), Khattab et al. (2010) and Khattab et al. (2012).

Among the various adsorbent systems available, the fungal biomass of Phanerochaete chrysosporium has been used as inexpensive and effective adsorbent for the removal of pesticides from aqueous solutions. On the other hand, the adsorption process using activated carbon remains the most widespread technique since it can remove all types of organic and inorganic pollutants from water.

Accordingly, the main aim of this work is to study the uptake of lindane by AC derived from rice straw in comparison with its biosorption by Phanerochaete chrysosporium under optimum conditions and the isothermal models for both adsorption and biosorption methods should be studied.

\section{Materials and Methods}

Certified standard of lindane $(\mathrm{Y}-\mathrm{HCH})$ 
with purity greater than $99.8 \%$ was purchased from Sigma-Aldrich Laborchemikalien, $\mathrm{GmbH}$ D-30918 Seelze. High grade solvents (n-hexane, diethyl ether, methanol, Dichloromethane) as well as phosphoric acid (85\%) were purchased from Merck, Darmstadt, Germany. Supelclean EVNI-18 SPE tubes $6 \mathrm{ml}(0.5 \mathrm{~g})$ was provided by Subelco Company, (Bellefonte, PA).

\section{Preparation of AC derived from Rice straw}

Rice straw was selected as carbonaceous raw material for the production of activated carbon obtained from one of the field that cultivates rice in Kafr El-Sheikh Governorate. The rice straw was washed, crushed and soaked in methanol for 4 hours followed by nitric acid ( 10 \%) for 1 hour to remove organic and inorganic matters from the surface; respectively, then rice straw was washed by distilled water and dried using an electric oven at $70{ }^{\circ} \mathrm{C}$ for $6 \mathrm{hrs}$. The air dried, crushed precursors was impregnated in 70 $\% \mathrm{H}_{3} \mathrm{PO}_{4^{\prime}}$ allowed to stand overnight and then pyrolyzed slowly up to a temperature of $500^{\circ} \mathrm{C}$ for $2 \mathrm{~h}$ at rate of $5^{\circ} \mathrm{C} / 1 \mathrm{~min}$. The acid was removed by washing with distilled water till the $\mathrm{pH}$ reached 6.8. The carbon product was dried at $110^{\circ} \mathrm{C}$ for $24 \mathrm{~h}$ using an electric oven.

Based on previous studies, it is stated that the maximum values of BET surface area and iodine adsorption capacity of rice straw achieved by the pyrolysing at $500{ }^{\circ} \mathrm{C}$ which is chosen based on previous studies (Liou and WU, 2009). This is because the reactants are only partial carbonized when the activation temperature is lower than $500{ }^{\circ} \mathrm{C}$. As a result, the pores may not fully develop, decreasing the surface area. However, at high temperature greater than 500 ${ }^{\circ} \mathrm{C}$, violent gasification reactions may cause a part of the micropore structure to be destroyed by collapsing or combining together (Oh and Park, 2002). As a result, decreasing microporosity leads to an increase in mesopore volume. The surface area and adsorption capacity decrease when the reaction temperature exceeds $500{ }^{\circ} \mathrm{C}$ (Guo and Rock straw, 2007). Moreover, the carbon yield for $\mathrm{H}_{3} \mathrm{PO}_{4}$ activation decrease as reaction temperature increases because by increasing of reaction temperature, the gasification becomes severe and ultimately leads to a reduction in the yield (Liou and Wu, 2009).

\section{Characterization of sorbent agent}

The carbon, hydrogen, nitrogen and sulfur analyses of activated carbon derived from rice straw were analyzed for element contents using CHNS elemental analyzer (Thermo Electron Flash EA 1112). The surface topography of the AC. was carried out using scanning electron microscope (SEM). The porous structure parameters were determined from nitrogen adsorption isotherms measured at $77 \mathrm{~K}$ with NOVA 2200 Gas Sorption Analyzer (Quantachrome). Prior to the measurements, the sample was outgassed overnight at $300{ }^{\circ} \mathrm{C}$. The specific surface area $\left(S_{B E T}\right)$ was estimated by BET equation. The amount of nitrogen adsorbed at the relatively pressure of $\mathrm{p} / \mathrm{p}_{0}=0.96$ was employed to determine pore volume $\left(V_{T}\right)$. The micropore volume $\left(V_{D R}\right)$ was calculated by applying the Dubinin-Radushkevich equation. The mesopore volume $\left(\mathrm{V}_{\text {mes }}\right)$ was calculated as a difference between the total pore volume $\left(V_{T}\right)$ and the micropore volume $\left(V_{D R}\right)$. The pore size distributions were determined by means of the Quenched Solid Density Functional Theory (QSDFT).

\section{Batch kinetic experiments}

AC was characterized and tested for their potential application for the removal of lindane $(\gamma-\mathrm{HCH})$ from aqueous solution. An amount of 0.1 $\mathrm{g}$ of $\mathrm{AC}$ was incubated with a $100 \mathrm{ml}$ of lindane (1mg/l) using water-bath shaker at $25{ }^{\circ} \mathrm{C}$ and agitated at $100 \mathrm{rpm}$ for 10, 15, 20, 30, 40, 45, 50, 60,75 , and $90 \mathrm{~min}$. After the agitation period, the samples were filtrated using filter paper whatman No. 40 and $10 \mu \mathrm{g}$ of hexachlorobenzene (HCB) as an internal standard was added to the supernatant and stirred for $10 \mathrm{~min}$.

The amount of lindane adsorbed at each time $\left(\mathrm{a}_{\mathrm{t}^{\prime}} \mathrm{mg}\right.$ lindane/g adsorbent) was calculated based on the following equation:

$$
Q_{f}=\left(C_{0}-C_{t}\right) V / m
$$

Where $C_{0}$ and $C_{t}$ are the liquid-phase concentrations (mg/l) of the investigated pesticide at initial and at any time; respectively; 
$V$ is the pesticide solution volume (I) and $m$ is the adsorbent mass (g). The equilibrium condition will be reached when no further decrease in the lindane concentration occurred.

\section{Adsorption isotherms}

To investigate the effect of initial concentrations on the kinetics of the investigated pesticides, one hundred $\mathrm{ml}$ of 1, 4, 6 and $8 \mathrm{mg} / \mathrm{l}$ lindane was placed into $250 \mathrm{ml}$ Erlenmeyer flask and incubated with $100 \mathrm{mg}$ of $\mathrm{AC}$. The optimum shaking time was selected based on the equilibrium study. The mixture was agitated using a shaking water-bath at $100 \mathrm{rpm}$.

The amount of adsorption at equilibrium, $Q_{e}$ (mg lindane/g AC) was calculated using the following mass balance equation 2 :

$$
Q_{e}=\left(C_{0}-C_{e}\right) V / m
$$

Where $C_{o}$ and $C_{e}(\mathrm{mg} / \mathrm{l})$ are the liquid-phase concentrations of lindane at initial and equilibrium; respectively; $V$ is the lindane solution volume (I) and $\mathrm{m}$ is the adsorbent mass ( $\mathrm{g}$ ).

\section{Conditions of lindane adsorbabilities}

To study the effect of carbon dosage on the retention of lindane from aqueous solution, three initial levels of carbon $(50,75$, and $100 \mathrm{mg}$ ) were incubated with different concentration levels of lindane (1,4 and $8 \mathrm{mg} / \mathrm{l}$ ) in $100 \mathrm{ml}$ of aqueous solution at $25 \pm 1^{\circ} \mathrm{C}$. The mixtures were agitated using a thermostated shaker waterbath at $100 \mathrm{rpm}$ for $50 \mathrm{~min}$ (equilibrium time).

To study the influence of temperature on the adsorption capacity against lindane from aqueous solutions, the same procedures were followed under two additional temperatures: 15 and $40{ }^{\circ} \mathrm{C}$. In order to study the influence of $\mathrm{pH}$ on the pesticides adsorption at $25 \pm 1^{\circ} \mathrm{C}$, different concentration levels of lindane $(1,4$, and $8 \mathrm{mg} / \mathrm{l})$ in $100 \mathrm{ml}$ water were incubated with $100 \mathrm{mg}$ ACs at the equilibrium time. The mixtures were agitated at $100 \mathrm{rpm}$ and the $\mathrm{pH}$ was adjusted using a $\mathrm{NaOH}(0.1 \mathrm{M})$ or $\mathrm{HCl}(0.1 \mathrm{~N})$ and measured by $\mathrm{pH}$ meter ( $\mathrm{pH}$-meter 764 Multi-Calimatic).

Preparation of Phanerochaete chrysosporium biosorbent
The fungal strain Phanerochaete chrysosporium NRRL-6361 was obtained from Northern Regional Research Laboratories (NRRL), Peoria, IL, USA and maintained on Malt Extract (ME) (15 g agar, $10 \mathrm{~g}$ malt extract, $5 \mathrm{~g}$ yeast extract, $5 \mathrm{~g}$ peptone and $5 \mathrm{~g}$ glucose/ I) at $\mathrm{pH}$ value 5.5. The fungi were grown at $35^{\circ} \mathrm{C}$ for 5 days. At the end of incubation period, the spores from colonized Petri plates were harvested and used to inoculate the conical flasks containing $100 \mathrm{ml}$ of ME culture medium. Cultures were incubated for 3 days at $35^{\circ} \mathrm{C}$ and $200 \mathrm{rpm}$. The obtained mycelium was used as a standard inoculum.

Experimental setup for lindane biosorption

Fifty $\mathrm{ml}$ of ME medium spiked with 10 $\mathrm{mg} / \mathrm{lof}$ lindane inoculated with $10 \%(\mathrm{v} / \mathrm{v})$ of the standard inoculum for 10- $240 \mathrm{~min}$. Cultures were incubated at $35^{\circ} \mathrm{C}$ and $200 \mathrm{rpm}$. The lindane residue was examined in the above different sorption times.

To specify the optimum concentration of biosorbent, $50 \mathrm{ml}$ of $\mathrm{ME}$ medium with two initial concentrations of lindane (10 and $20 \mathrm{mg} / \mathrm{l})$ were incubated with 1, 2, 4, 6, 8 and $10 \%(\mathrm{v} / \mathrm{v})$ of the biosorbent. Cultures were incubated at $35{ }^{\circ} \mathrm{C}$ and 200 rpm for 1 hour.

For isotherm study, different concentration of lindane $(25,30,35,40,45$, 50,55 and $60 \mathrm{mg} / \mathrm{l}$ ) was applied in $50 \mathrm{ml}$ of $\mathrm{ME}$ medium inoculated with $8 \%(\mathrm{v} / \mathrm{v})$ of the standard inoculum for $1 \mathrm{hr}$. the cultures were incubated at $35^{\circ} \mathrm{C}$ and $200 \mathrm{rpm}$.

For biosorption studies, the uptake of lindane were calculated based on the density of aqueous solution is 1 .

\section{Extraction of lindane from aqueous solution}

Extraction of lindane residue from aqueous solution was carried out using Solid Phase Extraction column (EVNI-18 SPE) through three main steps: (I) conditioning, the column was activated using $6 \mathrm{ml}$ of hexane: diethyl ether $(1: 1)$ two times followed by $6 \mathrm{ml}$ of methanol and then $6 \mathrm{ml}$ of deionized water. (II) Sample extraction, the sample was transferred to the column and slowly passed through SPE using vacuum at flow rate of $10 \mathrm{ml} / \mathrm{min}$. To ensure that the SPE packing does not dry between conditioning and sample 
addition, about $1 \mathrm{ml}$ of deionized water was remained above the top of packing material. (III) The column was dried for 10 min under vacuum and lindane residues were eluated two times using $1.5 \mathrm{ml}$ of hexane: diethyl ether (1:1). The eluate was evaporated under steam of nitrogen to $1.0 \mathrm{ml}$ to be ready for analysis. Lindane concentrations will be determined using Agilant 6890 HP gas chromatography using FID detector.

\section{Results \& Discussions}

Characterization of AC derived from rice straw The porosity and specific surface area $\left(S_{B E T}\right)$ of $A C$ are given in Table 1. The characterization of the adsorbent agents revealed that the surface area $\left(S_{B E T}\right)$ of $A C$ is $274 \mathrm{~m}^{2} / g$. Fig. 2 showed the pore size distribution (PSD) by means of the Quenched Solid Density Functional Theory (QSDFT) and it could be observed that the mesopore volume $\left(\mathrm{V}_{\text {mes }}\right)(0.228$ $\mathrm{cm}^{3} / \mathrm{g}$ ) represented $68 \%$ of total pore volume while the ratio of $V_{\text {mic }} / V_{\text {meso }}$ is 0.319 .

Table 1. Porous texture parameters determined by nitrogen sorption at $77 \mathrm{~K}$ and elemental analysis of $\mathrm{AC}$.

\begin{tabular}{|c|c|c|c|c|}
\hline \multicolumn{5}{|c|}{ Surface area and texture porosity } \\
\hline Activated carbon & $\mathrm{S}_{\text {BET }}\left(\mathrm{m}^{2} / \mathrm{g}\right)$ & $\mathrm{V}_{\mathrm{T}}\left(\mathrm{cm}^{3} / \mathrm{g}\right)$ & $V_{D R}\left(\mathrm{~cm}^{3} / \mathrm{g}\right)$ & $V_{\text {mes }}\left(\mathrm{cm}^{3} / \mathrm{g}\right)$ \\
\hline $\mathrm{AC}$ & 274 & 0.335 & 0.107 & 0.228 \\
\hline \multicolumn{5}{|c|}{ Elemental analysis (\%) } \\
\hline \multirow[t]{2}{*}{ Elemental } & $\mathrm{C}$ & $\mathrm{N}$ & $\mathrm{H}$ & $S$ \\
\hline & $34.11 \pm 0.27$ & $0.473 \pm 0.013$ & $1.82 \pm 0.14$ & BDL* \\
\hline
\end{tabular}
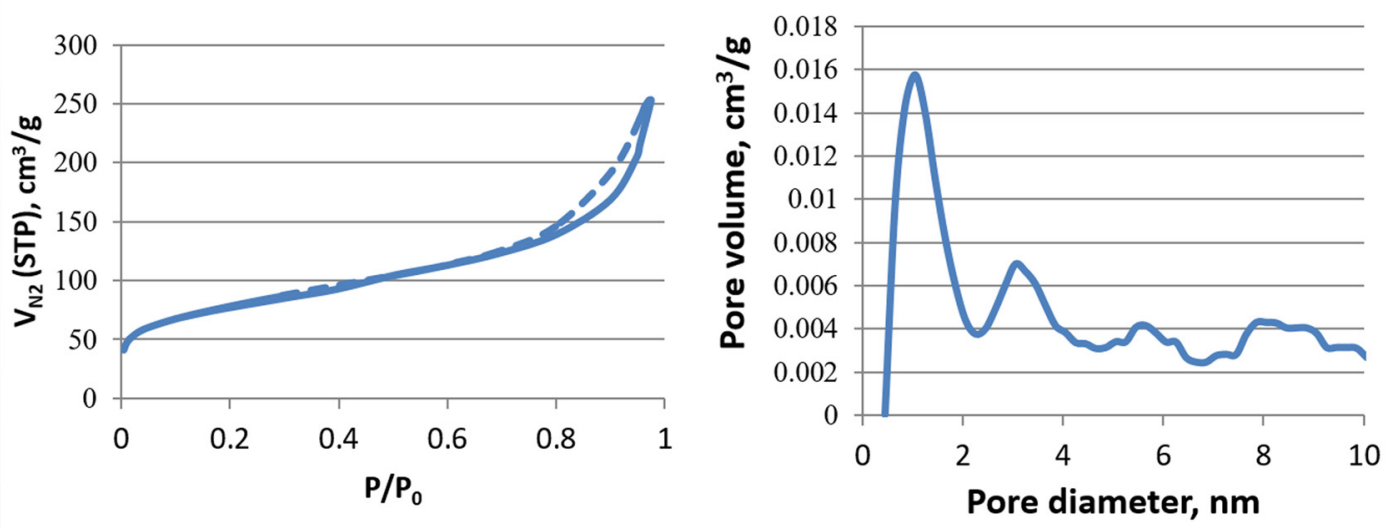

Figure 1. (a) N2 sorption adsorption-desorption, (b) Pore size distribution determined isotherms measured at $77 \mathrm{~K}$ by QSDFT.

The $\mathrm{C}, \mathrm{H}$ and $\mathrm{N}$ contents for the activated carbon derived from rice straw accounted for $36.4 \%$ of the total weight (w/W) (Table 1). However, the ash content is very high since it constituted $52 \%$ of the activated carbon (mainly silica). This finding is in accordance with Baxter (1993) who illustrated that the ash content of rice straw is high (10-17\%) compared to wheat straw (3\%), the silica in the ash represented the vast majority and may be reached to $75 \%$.

The SEM images reflect the efficiency of thermo-chemical activation by phosphoric acid in increasing the porosity of AC. As shown in Fig.3, the chemical composition was determined by Energy Dispersive X-ray Spectroscopy (EDX).
The main components of the AC are Silicon, Phosphorus, Carbon and oxygen. The oxygen at the surface of activated carbon indicates the presence of function groups; however it does not provide any information about their chemical composition (Moreno-Tovar et al., 2014). The phosphorus content revealed to the activation process using ortho-phosphoric acid (85\%). At such high concentration the acid may exist in different forms. As the reaction temperature increases, water molecules are eliminated resulting in $\mathrm{H}_{3} \mathrm{PO}_{4}$ transformation into acids of various chain lengths with a general formula of $\mathrm{Hn}_{+2} \mathrm{PnO}_{3} n_{+1}$. It enhances the acids interactions with lignocellulosic material and 
phosphorylation of cellulose (Jagtoyen and Derbyshire, 1998 and Olivares-Marín et al., 2006). This leads to formation of phosphate esters and increases in cross-linking reactions and pore development. The oligomerized $\mathrm{H}_{3} \mathrm{PO}_{4}$ that become part of the carbon matrix decomposes and involves in gasification reactions above 350$400{ }^{\circ} \mathrm{C}$ (Olivares-Marín et al., 2006). Therefore, acid impregnation increases the density of the sample carbonized at $400^{\circ} \mathrm{C}$. Above $450^{\circ} \mathrm{C}$, the

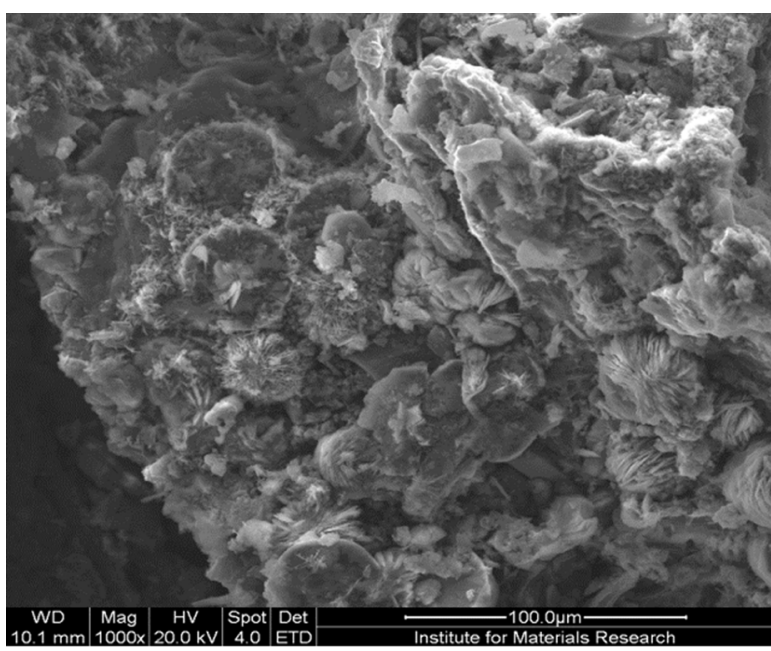

Figure 2. SEM images for AC derived from RS at magnification of $1000 \mathrm{x}$ and $4000 \mathrm{x}$

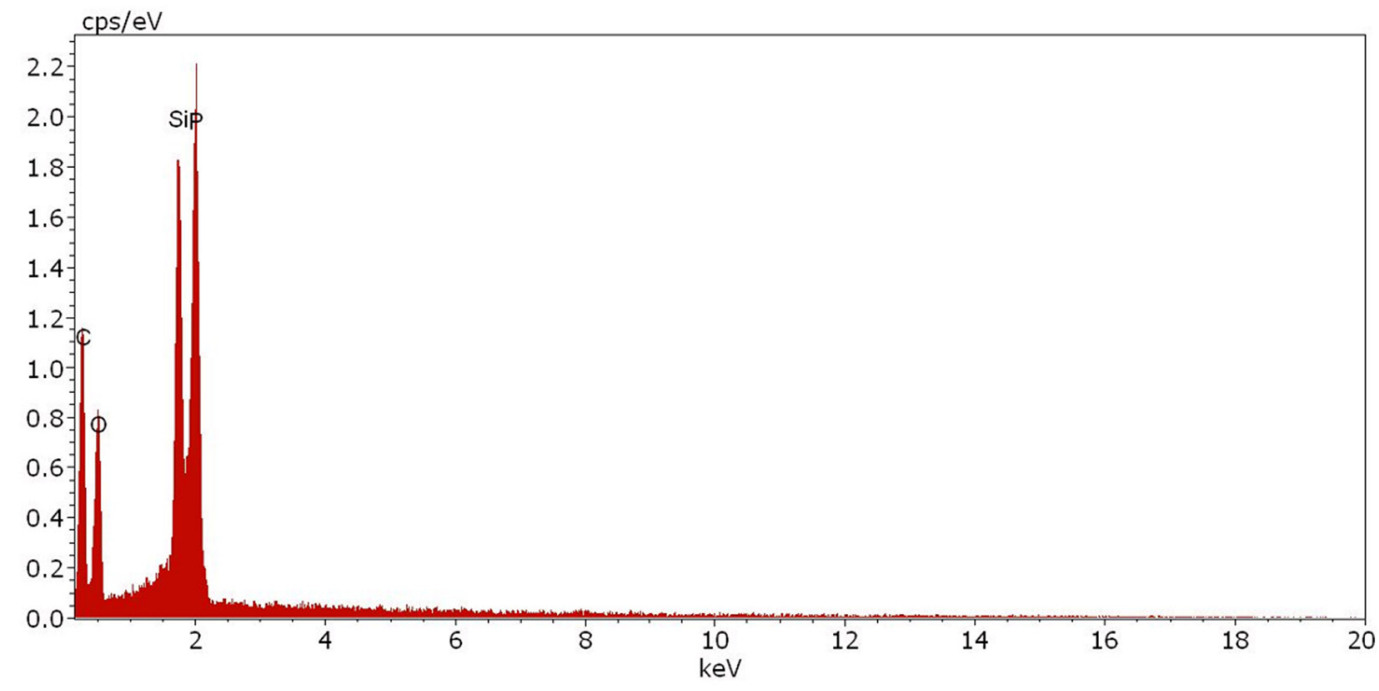

Figure 3. EDX spectrum of $A C$ derived from rice straw.

Effect of contact time

The concentration of lindane was observed at different time intervals in order to determine the optimum contact time at which maximum amount lindane can be adsorbed either physically on AC derived from rice straw or biologically by Phanerochaete chrysosporium. It was observed that gradual increase in adsorption
$\mathrm{H}_{3} \mathrm{PO}_{4}$ polymorphs decompose to eliminate $\mathrm{H}_{3} \mathrm{PO}_{4}$ from cellulose phosphate esters (Jagtoyen and Derbyshire, 1998). This generates more pores and hence relative decrease in density. Furthermore, between 500 and $600{ }^{\circ} \mathrm{C}$ the $\mathrm{H}_{3} \mathrm{PO}_{4}$ polymorphs melt. In such molten form and high temperatures, the reactions with carbon matrix increases. These develop more pores and release $\mathrm{P}_{4}, \mathrm{CO}_{2}, \mathrm{H}_{2} \mathrm{O}$ and other volatile materials (Olivares-Marín et al., 2006).

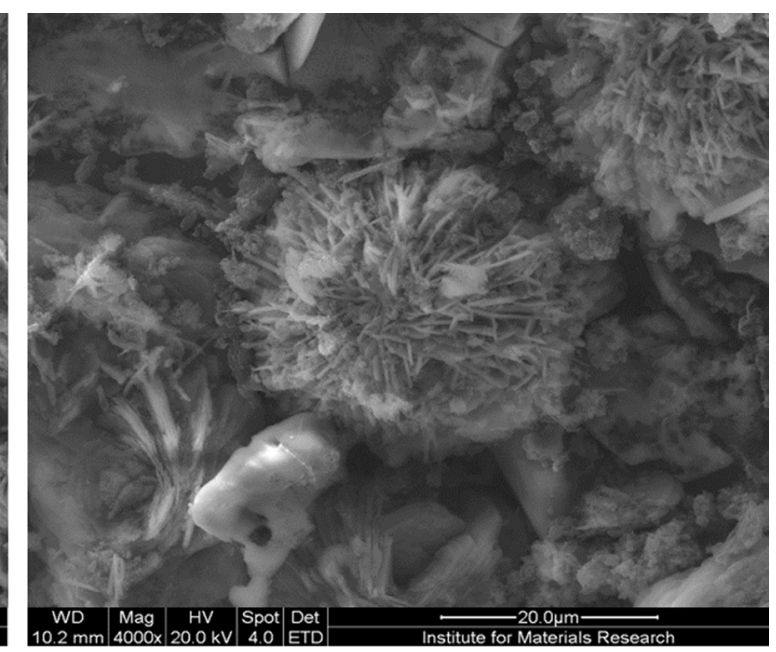

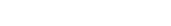
$\mathrm{keV}$

of lindane on either AC or Phanerochaete chrysosporium was noticed with increasing of time (Fig. 4).

The vast majority of adsorption process was so rapid within the first stage since $82 \%$ of lindane was absorbed within 20 min of contact time in case of $A C$, however 10 min was enough to reduce $90 \%$ of lindane using Phanerochaete 
chrysosporium since, rapid initial adsorption of lindane is a surface phenomenon (Kumar and Philip, 2006). During the second phase, a slight decrease in the adsorption kinetics was observed as the adsorption of lindane was increased by $8 \%$ with $\mathrm{AC}$ and $7.5 \%$ with Phanerochaete chrysosporium after $30 \mathrm{~min}$, and then the rate of adsorption become very slowly until $90 \mathrm{~min}$. Most likely because of slow diffusion of the lindane into the smaller pores and irregularities on the adsorbent surface (El Bakouri et al., 2009a). The final stage took place after $60 \mathrm{~min}$ of contact and remained even after $5 \mathrm{~h}$.

Equilibrium was attained faster using Phanerochaete chrysosporium than AC since, maximum removal was reached at $20 \mathrm{~min}$ in case of Phanerochaete chrysosporium while it takes 50 min with AC. After equilibrium time non significant increase was observed indicating that 20 min and 50 min are the optimum contact time for adsorption of lindane of AC. or its biosorption by Phanerochaete chrysosporium.

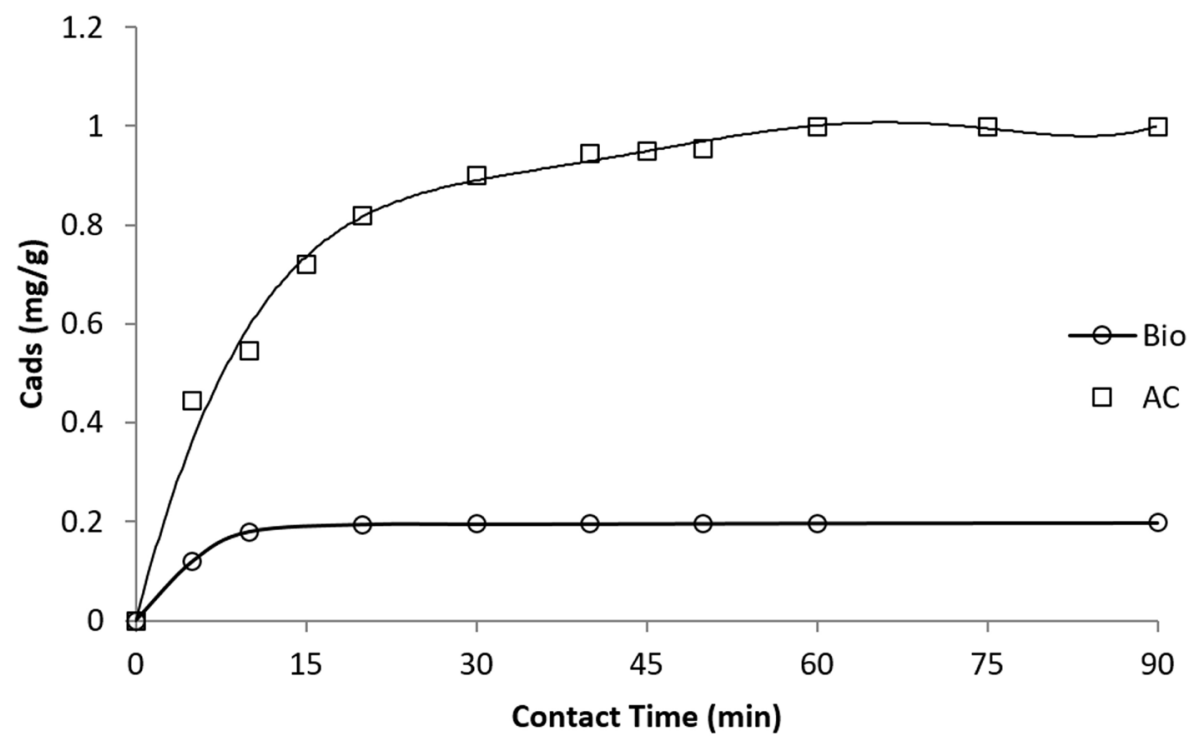

Figure 4. Effect of contact time on lindane uptake onto activated carbon and biosorbent of Phanerochaete chrysosporium. Experimental conditions for AC $10.1 \mathrm{~g}$ adsorbent, $1 \mathrm{mg} 1-1$ of lindane, $\left.\mathrm{pH} 7, \mathrm{~T}=25 \pm 1^{\circ} \mathrm{C}\right)$ For biosorbent $(10 \%(\mathrm{v} / \mathrm{v})$ of the standard inoculum, $10 \mathrm{mg} \mathrm{l}-1$ of lindane, $\mathrm{pH} 7, \mathrm{~T}=35$ $\left.\pm 0.1^{\circ} \mathrm{C}\right)$

A number of sorption studies have been published which show considerable variation in the time needed to establish equilibrium (El Bakouri et al., 2009b and Jamil et al., 2011). When equilibrium conditions are reached, the adsorbate molecules in the solutions are in a state of dynamic equilibrium with the molecules adsorbed by the sorbent. After pseudo equilibrium, less than a $1 \%$ variation of lindane concentration in the solution was observed even after $4 \mathrm{~h}$.

Effect of carbon dose and biosorbent concentration on the lindane uptake capacity:

Data presented in Fig.5a showed the effect of initial carbon dosage on the adsorption capacity for different levels of lindane $(1,4,8$ $\mathrm{mg} / \mathrm{l})$ from aqueous media. The results indicated that the adsorption of lindane from aqueous solutions was increased as the adsorbent mass increased. It is evident from the results presented in Fig. $5 a$ that, the removal percentage using 50 mg of AC ranged from 86 to $90 \%$. This percentage was increased and reached about $96 \%$ when the amount of carbon dose was increased to 100 mg. The result is logic, considering the available surface area and the total pore volume including micro and meso-pores.

In addition, the results presented in the same Fig. 5a illustrated that the maximum uptake of lindane reached $13.8 \mathrm{mg} / \mathrm{g}$ with $50 \mathrm{mg}$ of the sorbent and a concentration level $8 \mathrm{mg} / \mathrm{l}$ of lindane. In comparison with our study which used activated carbon derived from date stones for the removal of lindane from aqueous solution, the results were relatively similar to the current results since the removal of lindane was ranged from $70 \%$ to $90 \%$ at concentration level of 1 to 
$10 \mathrm{mg} / \mathrm{l}$. However, the uptake of lindane is higher with activated carbon derived from rice straw (13.8 $\mathrm{mg} / \mathrm{g}$ ) compared with its derived from date stones (11.3 mg/g) at the same conditions (ElKady et al, 2013a).

Regarding the effect of biosorbent concentration on the lindane uptake capacity. The result depicted in Fig. 5b indicated the sorption of lindane was increased by increasing biosorbent concentrations until $8 \%(\mathrm{v} / \mathrm{v})$ for both initial concentrations. Furthermore, the increasing of biosorbent concentration above $8 \%(\mathrm{v} / \mathrm{v})$ has no any significant increasing in biosorption efficiency. This is due to the saturation of all the binding sites available for lindane on the native biomass surface. A similar tendency has been reported for the biosorption of lindane by Subrata et al., (2009) and for the biosorption of pentachlorophenol by Brandt et al., (1997) and Jianlong et al., (2000). The removal percentage of lindane reached $98 \%$ and $96 \%$ at initial concentration levels of 10 and $20 \mathrm{mg} / \mathrm{l}$ with using of $8 \%$ biosorbent concentration. In general, it could be concluded that the concentration of the biosorbent is an important parameter influencing sorption process since it determines the sorption capacity of a biosorbent for a given initial concentration of the adsorbate at the operating conditions. So, the $8 \%(\mathrm{v} / \mathrm{v})$ of the biosorbent concentration was selected to be the optimum dose for all of the following lindane biosorption.

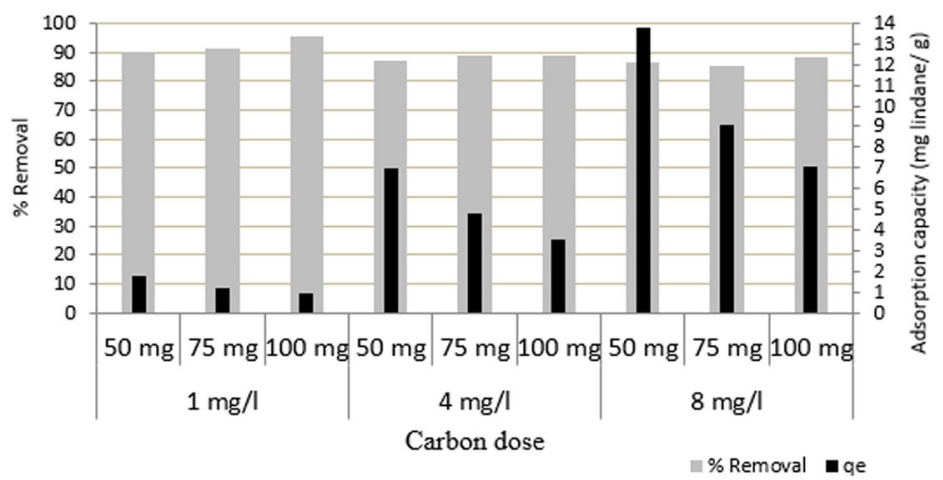

(a): Activated carbon

Experimental conditions: $(50,75,100 \mathrm{mg}$ of adsorbent; $1,4,8 \mathrm{mg}$ lindane/l; $\mathrm{pH} 7 ; \mathrm{T}=25 \pm 1^{\circ} \mathrm{C}$ ).

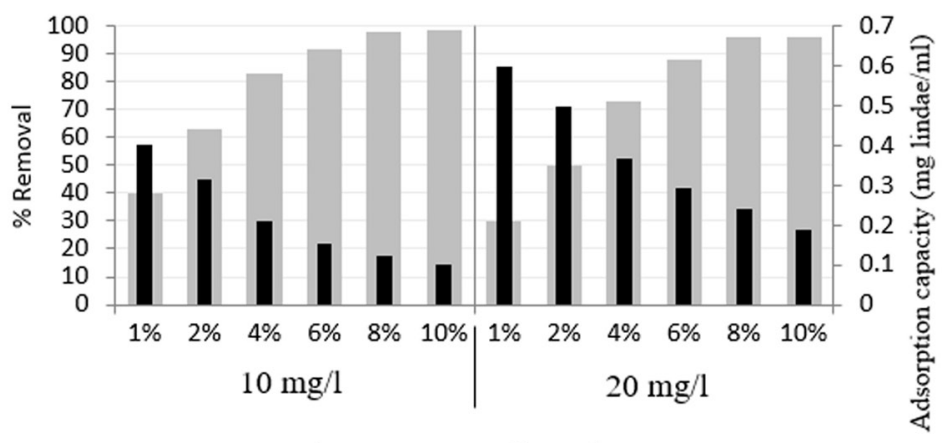

Initial concentration of biosorbent

(B): Biosorbent

Experimental conditions: $(1,2,4,6,8,10 \%$ of biosorbent; $10,20 \mathrm{mg}$ lindane $/ \mathrm{l} ; \mathrm{pH} 7 ; \mathrm{T}=25 \pm 1^{\circ} \mathrm{C}$ ).

Figure 5. Effect of initial carbon dose and biosorbent on \% removal and adsorption capacity against lindane.

Langmuir adsorption isotherm

Langmuir equation can be used to indicate sorption of lindane on specific homogenous sites within AC or Phanerochaete chrysosporium and intermolecular forces decrease rapidly with the distance from the sorption surface. Also this model shows the monolayer coverage of lindane on the surface 
of the understudied sorbent (Ibrahim et al., 2010). Langmuir isotherm shown in equation (3) correlates the adsorption of different concentrations of lindane $(25-60 \mathrm{mg} / \mathrm{l})$ at $35 \pm 0.1^{\circ} \mathrm{C}$.

$$
C_{e} / C_{a d s}=(1 / Q b)+(C e / Q)
$$

Where $C_{e}$ is the equilibrium concentration of lindane in solution, $C_{a d s}$ is the amount of lindane sorbed per unit mass onto AC or Phanerochaete chrysosporium. $Q$ and $b$ are Langmuir constants that represent the maximum monolayer coverage of sorbents with lindane and enthalpy of sorption respectively.

The correlation between $\mathrm{C}_{\mathrm{e}} / \mathrm{C}_{\text {ads }}$ and $\mathrm{C}_{\mathrm{e}}$ over the entire concentration range of lindane is shown in Fig 6. Sorption data showed significant description to Langmuir isotherm by $R^{2}$ values $\approx$ 0.99 as shown in Table 2.

According to the $Q$ parameter shown in Table 2, monolayer capacity of lindane biosorption by Phanerochaete chrysosporium is much more than adsorption of lindane by AC. Lindane concentration seems to reach saturation, which means that possible available sites in AC and Phanerochaete chrysosporium is clogged and new surface is needed for further adsorption.

Lindane molecule expected to pass through the channel of $A C$ in the hydrated form surrounded by water molecules (Leinonen and Lehto, 2001). Also, the charge density of adsorbed matter, the diameter of molecular sorbet have a great effect on adsorption either it is physical or biological. Since, higher adsorption of Phanerochaete chrysosporium than AC was recorded because of its higher surface area than that of AC (Jamil et al., 2011).

The essential features of the Langmuir isotherm may be expressed in terms of equilibrium parameter RL, which is a dimensionless constant referred to as separation factor or equilibrium parameter

$$
R_{L}=\frac{1}{1+\left(1+K_{L} C_{0}\right)}
$$

Where: $\mathrm{C}_{\mathrm{o}}=$ initial concentration $\mathrm{K}_{\mathrm{L}}=$ the constant related to the energy of adsorption (Langmuir Constant). $\mathrm{R}_{\mathrm{L}}$ value indicates the adsorption nature to be either unfavourable if $R_{L}>1$ ), linear if $R_{L}=1$, favourable if $0<R_{L}<1$ and irreversible if $R_{L}=0$. From the data calculated in table 2 , the $R_{L}$ is greater than 0 but less than 1 indicating that Langmuir isotherm is favorable.

Table 2. Langmuir equation constants of lindane uptake by AC and Bio

\begin{tabular}{ccccccc}
\hline \multirow{2}{*}{ Organic Cpd } & \multicolumn{2}{c}{$\mathrm{Q}(\mathrm{mmol} / \mathrm{ml})(\mathrm{mmol} / \mathrm{g})$} & \multicolumn{2}{c}{$1 / \mathrm{b}(\mathrm{l} / \mathrm{mmol})$} & \multicolumn{2}{c}{ Correlation Coefficient $\left(\mathrm{R}^{2}\right)$} \\
\cline { 2 - 6 } & Bio & AC & Bio & AC & Bio & AC \\
\hline lindane & 3.82 & 0.035 & 0.004 & 0.002 & 0.996 & 0.987 \\
\hline
\end{tabular}

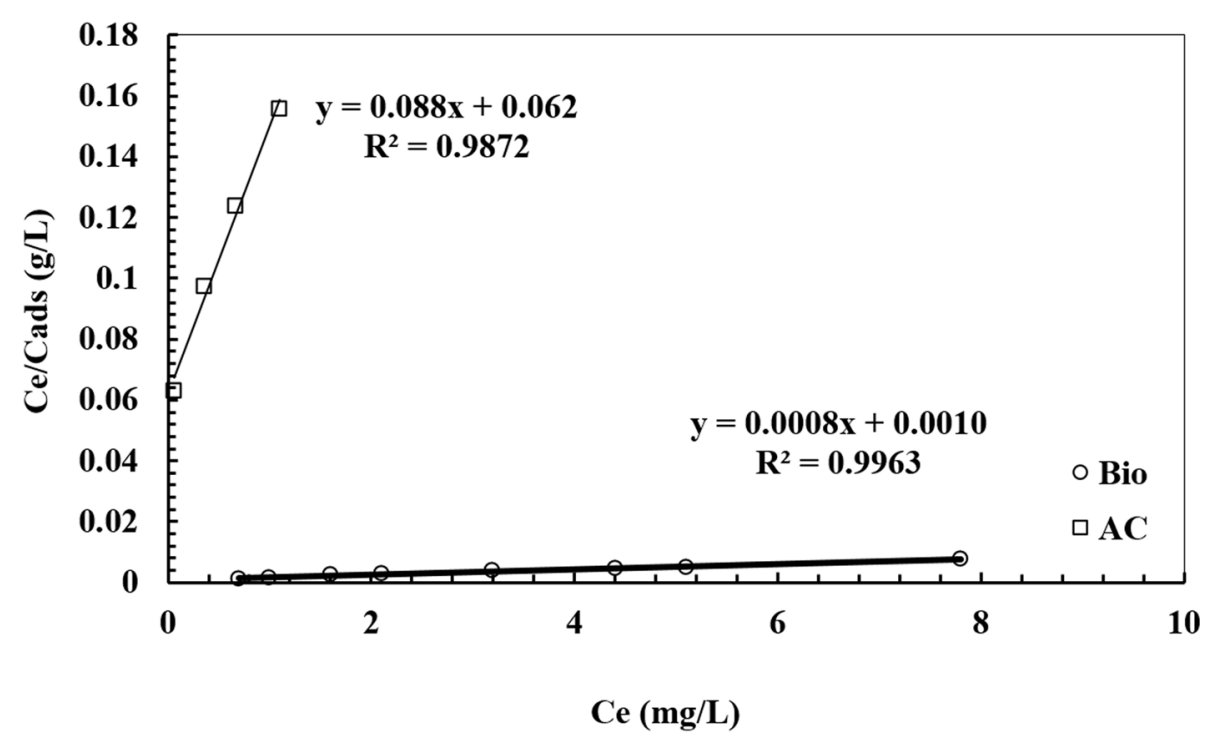

Figure 6. Langmuir isotherm for lindane adsorption and biosorption onto AC and Phanerochaete chrysosporium, respectively 
Freundlich isotherm

On opposite to Langmuir equation that assumes a monolayer capacity, Freundlich isotherm prove the adsorption or biosorption equilibrium on heterogeneous surfaces (Prasad et al. 2008, Rao and Viraraghavan, 2002). Through that isotherm, the surface heterogeneity and the exponential distribution of active sites and their energies are extensively expressed. Freundlich isotherm shown in equation (5) correlates the adsorption of different concentrations of lindane $(25-60 \mathrm{mg} / \mathrm{l})$ at $35 \pm 0.1^{\circ} \mathrm{C}$.

$$
\log C_{a d s}=\log K+1 / n \log C_{e}
$$

Where $C_{e}$ is the equilibrium concentration in $\mathrm{mg} / \mathrm{l}$ of lindane, Cads shows the amount of lindane adsorbed per gram of the adsorbent at equilibrium (mg/g) (Foo and Hameed, 2010). The constants $\mathrm{K}$ (Freundlich isotherm constant) and n (adsorption intensity) are calculated for each adsorption by Table 3, where $\mathrm{K}$ is a parameter related to the temperature. The value of $K$ is a measure of the adsorption capacity of sorbet and it increases as the amount of removed lindane per unit weight increases. On the other hand, $n$ is a characteristic constant for the adsorption system under study. The correlation between $\log C_{e}$ is and $\log C_{\text {ads }}$ is linear over the entire concentration range of lindane investigated and the values of $K$ and $n$ are calculated from the slop and intercept of that straight line. Adsorption and biosorption of lindane by AC and Phanerochaete chrysosporium respectively fit Freundlich isotherm since $r^{2}$ values were nearly 1 with both AC (0.994) and Phanerochaete chrysosporium (0.999).

$\mathrm{n}$ values for biosorption and adsorption were 3.08 and 1.53 respectively as shown in Table 3. These results showed that biosorption of lindane by Phanerochaete chrysosporium is much better than its adsorption by AC since, $\mathrm{n}$ values is between 2 and 10 as mentioned by Erdem et al. (2004). Meanwhile, $1 / n$ values are less than 1 either in biosorption or adsorption i.e value of $n$ is greater than unity, indicating that adsorption intensity is favorable at high concentrations. There is no prediction for any saturation of lindane by adsorption or biosorption. Accordingly, multilayer adsorption on the surface is expected due to mathematical prediction of infinite surface coverage (Hasany et al., 2002).

Finally, it can be concluded that Freundlich isothermal model is more fit experimentally than the Langmuir isotherm. Also, these results gave attention to the heterogeneity of the sorption sites either in biosorption or adsorption (Ibrahim et al., 2010).

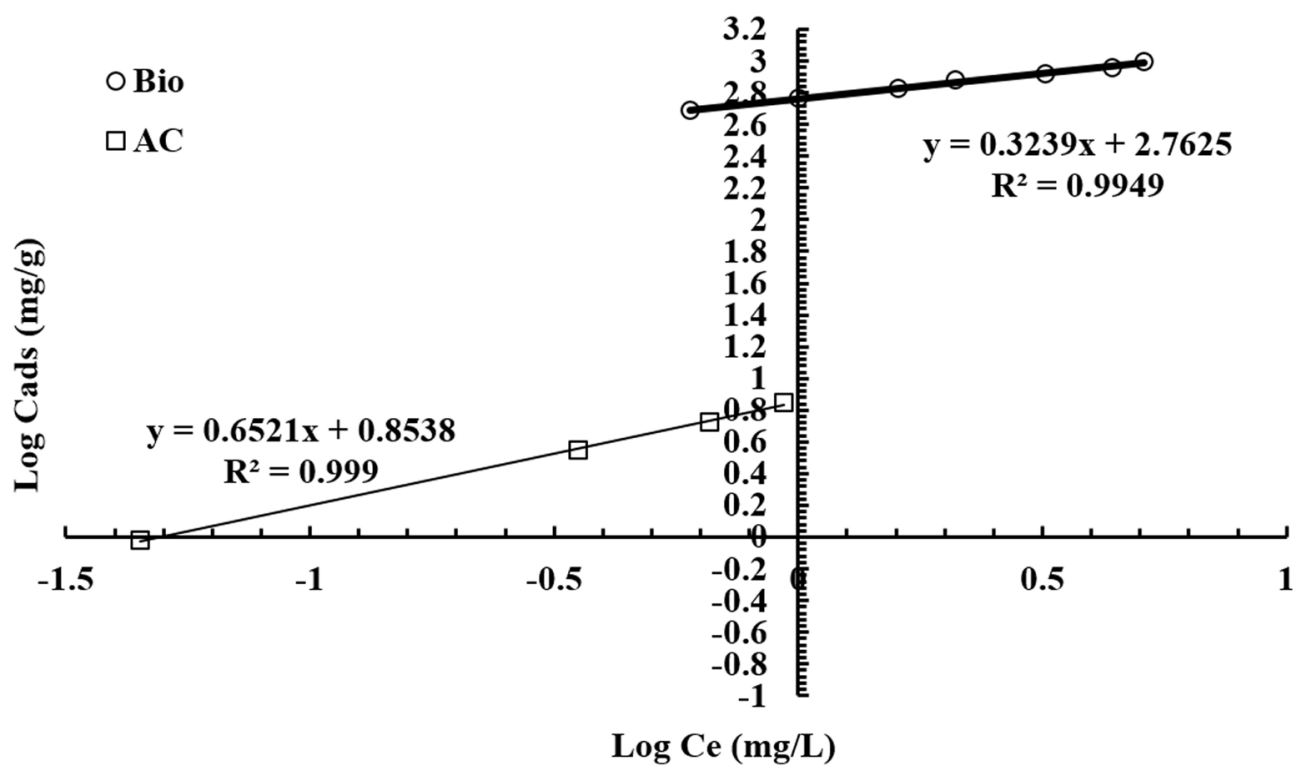

Figure 7. Freundlich isotherm for lindane adsorption and biosorption onto AC and Phanerochaete chrysosporium. 
Table 3. Freundlich adsorption constants for lindane uptake by AC and Biosorbent.

\begin{tabular}{|c|c|c|c|c|c|c|c|c|}
\hline \multirow{2}{*}{ Organic Cpd } & \multicolumn{2}{|c|}{ (mmol/ml) $(\mathrm{mmol} / \mathrm{g})$} & \multicolumn{2}{|c|}{$1 / n$} & \multicolumn{2}{|c|}{$\mathrm{n}$} & \multicolumn{2}{|c|}{$\begin{array}{c}\text { Correlation } \\
\text { Coefficient }\left(R^{2}\right)\end{array}$} \\
\hline & Bio & $A C$ & Bio & $A C$ & Bio & $A C$ & Bio & $A C$ \\
\hline lindane & 0.44 & 7.12 & 0.325 & 0.652 & 3.08 & 1.53 & 0.995 & 0.999 \\
\hline
\end{tabular}

\section{Conclusion}

In the current study, behavior of lindane uptake by Phanerochaete chrysosporium and AC derived from Rice Straw is investigated. Adsorption and biosorption by $A C$ and Phanerochaete chrysosporium were fit to Langmuir isotherm.

Saturation of lindane by adsorption or biosorption was not proved and infinite surface coverage was predicted i.e. Freundlich Isotherm is obeyed. $n$ values in Freundlich isotherm were 3.08 and 1.53 for biosorption by Phanerochaete chrysosporium and adsorption by AC, respectively indicating higher affinity for lindane uptake by Phanerochaete chrysosporium biosorption than activated carbon adsorption. This is in accordance with the higher maximum biosorption capacity for lindane by Phanerochaete chrysosporium (1250 mg/ml) than that of lindane adsorption by activated carbon $(11.36 \mathrm{mg} / \mathrm{g})$. The above mentioned data were assessed by the high percentage removal of lindane by biosorption than adsorption in shorter contact time.

\section{References}

AbdulKhalil, H.P.S., Jawaid, M., Firoozian, P., Rashid, U., Islam, A., and Akil, H. Md. 2013. Activated Carbon from Various Agricultural Wastes by Chemical Activation with $\mathrm{KOH}$ : Preparation and Characterization. Journal of Biobased Materials and Bioenergy 7: 1-7.

An, D., Guo, Y., Zou, B., Zhu, Y., Wang, Z. 2011 . A study on the consecutive preparation of silica powders and active carbon from rice husk ash. Biomass Bioenergy 35: 1227-1234.

Aksu. Z. 2005. Application of biosorption for the removal of organic pollutants: a review. Process Biochemistry 40: 997-1026.

Baxter, L.L. 1993. Ash deposition during biomass and coal combustion. A Mechanistic Approach. Biomass and Bioenergy 4: 85-102.

Brandt, S., Zeng, A.P., Deckwer, W.D. 1997. Adsorption and desorption of pentachlorophenol on cells of Mycobacterium chlorophenolicum PCP-1. Biotechnology and Bioengineering 55:
480-489.

Demirba, E., Kobya, M., Öncel, S., Sencan, S. 2002. Removal of Ni (II) from aqueous solution by adsorption onto hazelnut shell activated carbon: equilibrium studies. Bioresource Technology 84: 291-293.

ElBakouri, H., Usero, J., Morillo, J., Rojas, R., Ouassini, A. 2009a. Drin pesticides removal from aqueous solutions using acid-treated date stones. Bioresource Technology 100: 2676-2684.

El Bakouri, H., Morillo, J., Usero, J., Ouassini, A. 2009b. Natural attenuation of pesticide water contamination by using ecological adsorbents: application for chlorinated pesticides included in European water framework directive. Journal of Hydrology 364: 175-181.

El-Kady, A.A., Carleer, R., Yperman, J., Farah, J.Y. 2013a. Optimum conditions for adsorption of lindane by activated carbon derived from Date Stones. World Applied Science Journal 27: 269279.

El-Kady, A.A., Abdel Ghafar, H. H., Ibrahim, M.B.M., Abdel-Wahhab, M.A. 2013b. Utilization of activated carbon prepared from agricultural waste for the removal of organophosphorous pesticide from aqueous media. Desalination and Water Treatment 51: 7276-7285.

Erdem, E., Karapinar, N., Donat, R. 2004. The removal of heavy metal zeolites. Journal Colloid Interface Science 280: 309-314.

Fomina, M., Gadd, G.M. 2014. Biosorption: current perspectives on concept, definition and application. Bioresource Technology 160:3-14.

Foo, K.Y., Hameed, B.H. 2010. Insights into the modeling of adsorption isotherm systems. Chemical Engineering Journal 156: 2-10.

Guo, Y., Rockstraw, D.A. 2007. Activated carbons prepared from rice hull by one-step phosphoric acid activation. Microporous and Mesoporous Materials, 100: 12-19.

Guo, Y.P., Zhao, J.Z., Zhang, H., Yang, S.F. 2005. Use of rice husk-based porous carbon for adsorption of Rhodamine B from aqueous solutions. Dyes and Pigments, 66: 123-128.

Hasany, S.M., Saeed, M.M., Ahmed, M. 2002. Sorption and thermodynamic behavior of zinc(II)-thiocyanate complexes 
onto polyurethane foam from acidic olutions. Journal of Radioanalytical and Nuclear Chemistry 252: 477-484.

Ibrahim, H. S., Jamil, T.S, Hegazy, E.H. 2010. Application of zeolite prepared from Egyptian kaolin for removal of heavy metals: II. Isothermal Model. Journal of Hazardous Material 182: 842847.

Ignatowicz, K. 2009. Selection of sorbent for removing pesticides during water treatment. Journal of Hazardous Material 169: 953-957.

Jagtoyen, M., and Derbyshire, F. 1998. Activated carbons from yellow poplar and white oak by $\mathrm{H}_{3} \mathrm{PO}_{4}$ activation. Carbon 36: 1085-1097.

Jamil, T.S., Gad-Allah, T.A., Ibrahim, H.S., Saleh, T.S. 2011. Adsorption and isothermal models of atrazine by zeolite prepared from Egyptian kaolin. Solid State Sciences 13: 198-203.

Jianlong W., Yi, Q., Horan, N., Stentiford, E. 2000. Bioadsorption of pentachlorophenol (PCP) from aqueous solution by activated sludge biomass. Bioresource Technology 75: 157-61.

Ju Y., Chen, T., Liu, J.C. 1997. Study on the biosorption of lindane. Colloids and Surfaces B: Biointerfaces 9: 187-196.

Kadirvelu, K., Karthika, C., Vennilamani, N., Pattabhi, S. 2005. Activated carbon from industrial solid waste as an adsorbent for the removal of Rhodamine-B from aqueous solution: Kinetic and equilibrium studies. Chemosphere 60: 1009-1017.

Khattab A.A., Ihab, A.M., Mohamed, K.A. 2010. Molecular analysis of genetically improved therapeutic Saccharomyces cerevisiae strains with high selenium uptake. Journal of American Science 6: 326-337.

Khattab A.A., Abdel Ghafar H.H., Ibrahim M.I.M. 2012. Enhancement of phenol biosorption by genetically improved of Rhodosporidium toruloides strains. Journal of Applied Science Research 8: 3600-3607.

Kumar, M., Philip, L. 2006. Adsorption and desorption characteristics of hydrophobic pesticide endosulfan in four Indian soils. Chemosphere 62: 1064-1077.

Leinonen, H., Lehto, J. 2001. Purification of metal finishing waste waters with zeolites and activated carbons. Waste Management and Research 19: 45-57.

Liou, T-H, WU, S-J. 2009. Characteristics of microporous/mesoporous carbons prepared from rice husk under base- and acid-treated conditions. Journal of Hazardous Material 171: 693-703.
Lopez, G., Olazar, M., Artetxe, M., Amutio, M., Elordi, G., Bilbao, J. 2009. "Steam activation of pyrolytic tyre char at different temperatures. Journal of Analytical and Applied Pyrolysis 85: 539- 543

Moreno-Tovar, R., Terrés, E., Rangel-Mendez, J.R. 2014. Oxidation and EDX elemental mapping characterization of an ordered mesoporous carbon: $\mathrm{Pb}(\mathrm{II})$ and $\mathrm{Cd}(\mathrm{II})$ removal. Applied Surface Science 303: 373-380.

Olivares-Marín, M., Fernández-González, C., Macías-García, A., Gómez-Serrano, V., 2006. Thermal behaviour of lignocellulosic material in the presence of phosphoric acid. Influence of the acid content in the initial solution. Carbon 44: 2347-2350.

Oh, G.H., Park, C.R. 2002. Preparation and characteristics of rice-straw-based porous carbons with high adsorption capacity. Fuel 81: $327-336$

Özçimen, D., and Ersoy-Meriçboyu, A. 2009. Removal of copper from aqueous solutions by adsorption onto chestnut shell and grape seed activated carbons. Journal of Hazardous Material 168: 1118-1125.

Park, D., Yun, Y.-S., Park, J.-M. 2010. The past, present, and future trends of biosorption. Biotechnology and Bioprocess Engineering 15: 86-102.

Prosen H., Troha, A., Zupancic-kralj, L. 2002. Studies of interaction between some organochlorine insecticides and humic acid using solid phase microextraction and gas chromatography. Acta Chimica Slovenica 49: 561-573.

Prasad, M., Xu, H.Y., Saxena, S. 2008. Multicomponent sorption of $\mathrm{Pb}(\mathrm{II}), \mathrm{CU}(\mathrm{II})$ and $\mathrm{Zn}(\mathrm{II})$ onto low-cost mineral adsorbent. Journal of Hazardous Material 154: 221-229.

Rahman, M.A., Amin, S.M.R., Alam, A.M.S. 2012. Removal of Methylene Blue from Waste Water Using Activated Carbon Prepared from Rice Husk. Dhaka University Journal of Science 60: 185-189.

Rao, J.R., Viraraghavan, T. 2002. Biosorption of phenol from a aqueous solution by Aspergillus niger biomass. Bioresource Technology 85: 165171.

Singh, S.R., Singh, A.P. 2012. Treatment of Water Containg Chromium (VI) Using Rice Husk Carbon as a Newlow Cost Adsorbent. International Journal of Environmental Research 6: 917-924.

Sivakumar, B., Kannan, C., Karthikeyan, S. 2012. Preparation and characterization of activated carbon prepared from balsamodendron caudatum wood waste through various 
activation processes. Rasyan Journal of Chemistry 5: 321-327.

Subrata G., Sujoy, K.D., Arun, K.G., Asis, K.S. 2009. Adsorption behavior of lindane on Rhizopus oryzae biomass: Physico-chemical studies. Journal of Hazardous Material 172: 485-490.

US-Environmental Protection Agency (US-EPA), Federal Register, 77(58), pp: 17898-18050 (2012).

Yavuz, H., Denizli, A., Gungunes, H., Safarikova, M., Safarik, I. 2006. Biosorption of mercury on magnetically modified yeast cells. Separation and Purification Technology 52: 253-260. 